\title{
The Dilemma of Grammatical Data in Travel Dictionaries
}

\author{
Birger Andersen (ba@asb.dk) and Patrick Leroyer ( $p l @ a s b . d k)$, \\ Centre for Lexicography, Aarhus School of Business, \\ University of Aarhus, Aarhus, Denmark
}

\begin{abstract}
Travel dictionaries are edited with a view to helping international tourists with no or very little previous knowledge of the foreign language. They aim to solve communicative problems in a number of specific situations in which tourists wish to engage in conversation. However, they also have to deal with the absence of the necessary listening and speaking skills of their users. The lexicographic information is normally twofold, as it includes a selection of relevant words and sentences as well as a selection of the grammatical rules that govern the integration of these words and sentences into tourist conversation - from words to utterances so to speak. In this article, we will focus on the selection and presentation of the grammatical data in order to investigate how they contribute to the fulfilment of their primary functions. Our thesis is that the grammatical data have to deal with a dilemma: helping tourists understand and be understood during a conversation while also helping them acquire some basic knowledge of the grammatical system of the foreign language.
\end{abstract}

Keywords: TRAVEL DICTIONARIES, BILINGUAL DICTIONARIES, LEARNERS' DICTIONARIES, ORAL TEXT RECEPTION, ORAL TEXT PRODUCTION, GRAMMATICAL DATA, SYNCHRONOUS CONSULTATION, ASYNCHRONOUS CONSULTATION

Opsomming: Die dilemma van taalgegewens in reiswoordeboeke. Reiswoordeboeke word opgestel met die doel om internasionale toeriste met geen of baie min kennis van 'n vreemde taal te help. Hulle beoog om kommunikasieprobleme op te los in 'n aantal spesifieke situasies waarbinne toeriste graag in gesprek wil tree. Hulle moet egter ook die afwesigheid van die nodige luister- en spreekvaardighede van hul gebruikers hanteer. Die leksikografiese inligting is gewoonlik tweeledig omdat dit 'n keuse van toepaslike woorde en sinne insluit sowel as 'n keuse van die taalreëls wat die integrasie van hierdie woorde en sinne in toeristegesprekke bepaal - van woorde tot uitinge as ' $t$ ware. In hierdie artikel sal ons fokus op die keuse en aanbieding van taalgegewens ten einde na te gaan hoe hulle tot die verwesenliking van hul primêre funksies bydra. Ons beskouing is dat die taalgegewens ' $n$ dilemma moet hanteer: om toeriste te help om te verstaan en verstaan te word tydens ' $n$ gesprek, en om hulle terselfdertyd te help om ook ' $n$ basiese kennis van die taalsisteem van die vreemde taal op te doen.

Sleutelwoorde: REISWOORDEBOEKE, TWEETALIGE WOORDEBOEKE, AANLEERDERSWOORDEBOEKE, MONDELINGE TEKSONTVANGS, MONDELINGE TEKSPRODUKSIE, TAALGEGEWENS, SINCHRONIESE RAADPLEGING, ASINCHRONIESE RAADPLEGING 


\section{Inheriting the grammatical characteristics of bilingual dictionaries}

Functionally speaking, lexicographic tools for tourists, including the so-called travel dictionaries and phrasebooks, ${ }^{\dagger}$ share a large number of lexicographic characteristics with the related 'ordinary' bilingual dictionaries. They are conceived and designed to help their intended L1 native users encountering communicative problems (mostly in conversations) by providing L1-L2, and to a certain degree L2-L1, foreign language assistance in the form of equivalents to single words and multi-word expressions, and to a range of prefabricated sentences to be used in conversation in conventional tourist situations. Our study of a number of these dictionaries reveals that in almost all cases the lexicographic information also includes the distribution of a substantial amount of grammatical data which can be accessed in the situational articles and in the bidirectional, bilingual wordlists, and mostly in a specific grammar section in L1 - a so-called mini-grammar. Information is normally provided from word to sentence level - phonetics, morphology, syntax, semantics as well as style and pragmatics, and even at the cultural level.

Our first hypothesis is that in travel dictionaries, the authors' decision to include a substantial amount of grammatical data at all levels is motivated by the authors' wish to exploit and even surpass the lexicographic bilingual legacy, as the value of including grammatical data in bilingual dictionaries has been broadly acknowledged for the past thirty years. It seems therefore reasonable to assume that travel dictionaries have merely inherited the characteristics of this lexicographic tradition from a bilingual perspective. Many metalexicographic contributions have dealt with the nature and the distribution of the grammatical data in the articles or in a certain type of dictionary grammar proper (Andersen 2007, Mugdan 1989, Mogensen 2005, Tarp 2006). The function of the grammatical data has also been discussed, and there seems to be a general agreement on the superiority of a production grammar (Andersen 2007: 133, Tarp 2006: 281): helping the L1 user to produce texts in the L2. Although it is not explicitly stated, all metalexicographic contributions deal with written text production, and nothing is being said about oral text production in L2 and oral text reception of L2, which obviously are the two primary functions of lexicographic tools designed for tourists.

\section{Inheriting the grammatical characteristics of learners' dictionaries}

What truly distinguishes travel dictionaries from bilingual dictionaries is the widely accepted metalexicographic identification of their intended users and user situations:

- users with no or very little previous knowledge of the foreign language, and

users who need actual communicative assistance in relevant tourist situations. 
While being completely in line with the above stated description of the user group profile, Abend (1991: 2903) should be credited for insisting on the dictionary as a lexicographic tool:

Das Reisewörterbuch (= RWB) ist als lexikographisches Hilfsmittel (our italics) für Reisende gedacht, die nur geringe oder keine Kenntnisse der Sprache ihres Urlaubslandes besitzen.

The travel dictionary as a lexicographic tool is aimed at travellers who have only very little or no knowledge of the language of their country of destination.

We could not agree more on the purpose of the travel dictionary as a tool, but find it very difficult to accept the definition of the user profile. The problem is obviously how travel dictionaries can possibly fulfil their communicative function and really help their intended users in the foreseen situations. As argued in Leroyer $(2007,2008)$, it is fairly obvious that tourist dictionaries are incapable of helping tourists who have no or little previous knowledge of the foreign language to communicate orally in it. That also goes for the grammatical assistance included in the lexicographic tool. To engage in a conversation in a foreign language presupposes some previous degree of foreign language knowledge and ability, including both listening competences and listening skills, and no matter how, the grammatical assistance will not help without these competences and skills. In other words, the real users of travel dictionaries should truly be identified and described as active learners of the foreign language at a beginner level, bound to encounter basic conversational problems in tourist relevant communication situations. Abend (1991: 2904) rightly claims that travel dictionaries are designed to be punctually consulted during travel:

Das RWB dient als Nachschlagewerk auf Reisen, um aktuelle Kommunikationsprobleme durch punktuelle Konsultation zu beheben.

The travel dictionary serves as a reference work on travel in order to solve current communication problems through punctual consultation.

but immediately admits that other user situations are perfectly conceivable:

RWB werden auch für die Reisevorbereitung [...] verwendet.

Travel dictionaries are also used for travel preparation.

From this consultation perspective, our second hypothesis is that the authors' decision to include substantial grammatical data in travel dictionaries must be seen as an attempt to compensate for a strongly suspected deficiency with respect to communicative assistance. This is done by giving access to the consultation of basic, pedagogically structured information on the language system and on its use: 'How the language works'. Travel dictionaries thus become hybrids: bilingual and learners' dictionaries at the same time. From a functional perspective, they are always consulted in temporally determined scenarios, in which communication and knowledge-oriented situations alternate (see also 
Tarp 2006: 243-283 for a comprehensive overview of the lexicographic functions with regard to distribution of, and access to grammatical data in learners' dictionaries):

(a) a knowledge-oriented prospective consultation taking place prior to travelling, in which travel dictionaries are systematically used as pedagogical tools in connection with a basic foreign language learning process,

(b) a communication-oriented introspective consultation taking place while travelling, in which travel dictionaries are punctually used as practical tools in order to obtain immediate assistance with respect to current communication problems, and

(c) a knowledge-oriented retrospective consultation in which travel dictionaries are systematically used to check on and eventually correct acquired knowledge, or to acquire new knowledge insofar as past encountered communication situations have revealed insufficient foreign language competence and skills (and have thus revealed insufficient dictionary assistance), or from the perspective of preparing a new travel to the same destination.

\section{The consultation and the functions of grammatical data}

As argued above, grammatical assistance can prove to be useful in a number of user situations in which the user punctually consults the dictionary to solve an actual communicative problem, or systematically in order to acquire the necessary knowledge on the language system and its usage as part of the language learning process. Below, we list the main interrelated lexicographic functions and consultation scenarios, in which the intended tourist user is a beginner, but has some basic previous knowledge of the foreign language, or is attending a language course:

Cognitive function - prospective consultation and foreseen general problems

(a) asynchronous assistance - learning how to communicate in specific tourist situations as a result of foreseen general problems because of lack of foreign language competences and skills

Communicative functions - introspective consultation and actualised specific problems

(b) synchronous assistance in connection with written text reception as a result of actual, specific problems in specific tourist situations

(c) synchronous assistance in connection with oral text production as a result of current, specific problems in specific tourist situations 
(d) synchronous assistance in connection with oral text reception as a result of current, specific problems in specific tourist situations

Cognitive functions - retrospective consultation and experienced specific and general problems

(e) asynchronous assistance to correct communication problems as a result of experienced specific communication problems encountered in (b)-(d)

(f) asynchronous assistance to pursue the ongoing learning process as a result of experienced general communication problems encountered in (b)-(d), and prompted by (a)

We are now in a position to investigate the selection and presentation of grammatical data in travel dictionaries and compare them with the functions identified above in their temporally determined consultation scenarios. But first, we have to briefly describe the different levels of user competence and their associated grammatical data.

\section{Eight levels of grammatical user competence from a normative per- spective}

Taking grammar in its broader sense, we can establish eight different linguistic competences which - if acquired and possessed by a non-native speaker will bring him/her very close to the linguistic competences of the native speaker.

(1) Phonetic competence

The speaker is capable of pronouncing words and phrases so as to make him-/herself understood. The speaker is also capable of understanding speech.

(2) Orthographic competence

The speaker (writer) is capable of spelling words in correspondence with the orthographic conventions of the language.

(3) Formal (or morphological) competence

The speaker is capable of correctly inflecting nouns for number, verbs for tense, adjectives for comparative and superlative, etc. etc. Formal competence also involves the following: choosing correctly (in English) between the -ing form and the infinitive after specific verbs, choosing the correct subject-verb agreement, choosing the correct relative pronoun, etc., etc.

(4) Structural (or syntactic) competence

The speaker is capable of placing the correct number of clause and phrase constituents in the correct order in the clause and phrase. It 
involves, for example, correct constituent order in inversion, correct order of premodifying adjective phrases in the noun phrase, correct order of modal and other auxiliaries in the verb phrase, etc. etc.

(5) Semantic (or terminological) competence

The speaker is capable of choosing the correct/appropriate word in any given speech situation.

(6) Stylistic competence

The speaker is capable of selecting lexical and grammatical elements which are appropriate for any given speech situation. The selected lexical and grammatical elements match the levels of formality and politeness required by the speech situation.

(7) Pragmatic competence

The speaker is capable of selecting the appropriate speech act and phrasing it correctly to accomplish his/her pragmatic goals in any given speech situation.

(8) Cultural competence

The speaker is capable of selecting the appropriate speech act and phrasing it correctly while using the appropriate body language conventions of the destination country in a particular speech situation.

There is some overlap between (6) and (7) since levels of politeness and formality are interrelated with choices between direct and indirect speech acts. There is also some overlap between (4) and (7), since a change in constituent order in a given speech act may create a different speech act (for example from statement to question). Finally, there is some overlap between (6), (7) and (8), since cultural conventions in all cases influence the speakers' choice of appropriate cultural phrases.

Linguistically speaking, these normative levels are all represented in tourist dictionaries (1)-(4) ((1)-(7) and (8) in the case of 'exotic' languages) as categories of information. Lexicographically speaking, the question, however, is the capacity of the information given by these lexicographic data to bring the necessary assistance to the communicative needs and problems of the tourist users. In the following, we will study the selection and presentation of the grammatical information.

\section{The shortcomings of grammatical data from a functional perspective}

\subsection{Helping with the sounds}

Phonetic information is given in all the dictionaries investigated. The information is normally accessible both in the articles and in the pronunciation section 
of the mini-grammars. In the Danish dictionaries, this information firstly takes the form of pronunciation tables using the International Phonetic Alphabet (IPA). In the Gyldendal dictionaries (GSEP 2005, GSFP 2005), there are also transcriptions (using the IPA) of all the phrases and all the words in the dictionaries. The Politiken dictionaries (PER 2005, PFR 2005, FDDFMO 2002) only have occasional transcriptions of words in the dictionaries, presumably those the writers of the dictionaries feel present special pronunciation difficulties.

We must assume that the use of the IPA will be a problem for those tourists who have had no formal language training. Many of the phonetic symbols of the IPA do not resemble letters in any Romance or Germanic language at all. It would therefore require a very thorough study if the tourist were to make sense of these pronunciation tables and the transcriptions.

In the English dictionaries, there are also pronunciation tables and transcriptions of phrases and words. However, the transcriptions used here are 'homemade' and different from one dictionary to the next. One dictionary has the following to say about the transcription system used:

In this dictionary, the German has been written in a system of imitated pronunciation so that it can be read as though it were English. (RGG 2006: 241)

The problems with these transcription systems can be illustrated by a few examples. The French term 'Saucisse de Strasbourg' (beef sausage) is transcribed in the following ways:

$$
\begin{array}{ll}
\text { RGF 2006: } & \text { [sossees duh strazboorg] } \\
\text { LPF 2003: } & \text { [so•sees der straz } \bullet \text { boor] }
\end{array}
$$

And the German term 'Bauernfrühstück' (bacon and potato omelet) is transcribed as follows:

$$
\begin{array}{ll}
\text { RGG 2006: } & \text { [bowern-frooshtook] } \\
\text { LPG 2003: } & \quad[\text { bow } \bullet \text { ern•frü•stück] }
\end{array}
$$

Since none of these transcriptions correspond to any orthographic pattern in English (see Wen-Chao Li 2007 for a critical survey of the many problems linked to the choice of adequate transliteration systems), it is indeed doubtful whether they will be of any assistance to tourists with respect to producing a correct or even comprehensible pronunciation of the terms. The problem is compounded when tourists have to struggle with transcriptions of longer phrases such as the following from LPF (2007: 136):

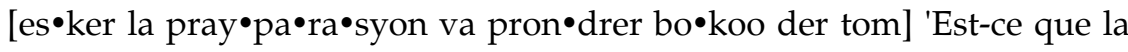
préparation va prendre beaucoup de temps'

So far, we have looked at pronunciation and transcription only from the productive perspective. A number of the dictionaries also attempt to provide 
assistance with pronunciation from a receptive angle, sometimes under headings such as 'Listen for' (Lonely Planet), sometimes as part of whole conversational exchanges as in the Rough Guide dictionaries, as for example the following from RGF (2006: 23):

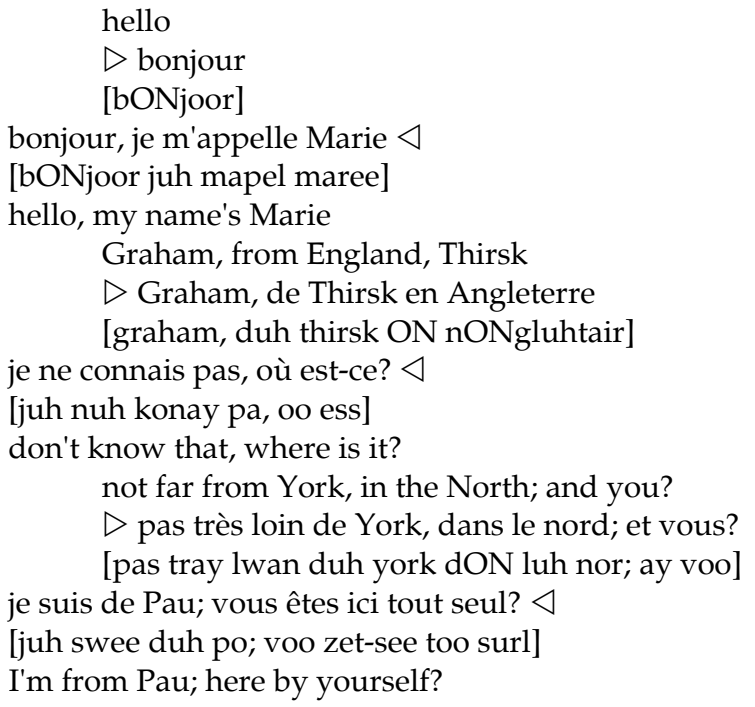

Apart from the fact that the tourist still has to struggle with the 'homemade' transcription system, the conversational exchange is so idiosyncratic that neither the productive nor the receptive elements have any general value whatsoever.

Either too complex, misleading or idiosyncratic, the phonological data accessible in the articles fail to help tourists solve the actual communicative problems attributable to the production and recognition of the sounds of the foreign language (functions (b) and (c)) in the case of punctual consultation situations. In the case of systematic consultation situations (functions (a), (e) and (f)), the data accessible in the pronunciation section of the mini-grammars are far too condensed to fulfil their cognitive function and help the tourist user acquire a satisfactory level of basic phonological competence. As poetically stated by the LPEA (2002: 11), descriptive, representative knowledge of the sounds of Amharic Ethiopian is simply not enough; it must be complemented by perceptive knowledge acquired through practice in order to develop adequate speaking and listening skills:

Tune into the sounds of Ethiopia's streets for tips on pronunciation: a mini-bus worker trilling his $\mathbf{r}$ as he calls the destination, a.rat ki.lo!: a vendor clicking her k's as she advertises her spicy snacks, ko.lo, ko.lo! [...] with a bit of practice, you'll be told you're gob.beuz, 'brilliant', by native Amharic speakers. 


\subsection{Helping to spell correctly}

Orthographic information is irrelevant in our context, since we are concerned only with oral production and reception. In actual fact, none of the dictionaries investigated give any explicit orthographic information, although it could be relevant for function (b), written text reception, particularly in the case of languages using other script systems, such as syllabary in LPEA 2002.

\subsection{Helping to inflect correctly}

Explicit morphological information is given in the so-called 'mini-grammars' or 'How the language works' sections of the dictionaries. We find there the essential inflectional rules with respect to the plural ending of nouns, the comparative and superlative endings of adjectives (where relevant), gender endings of nouns and adjectives (where relevant), information about subject-verb agreement, etc. etc. In this respect, it seems as if the dictionaries aim to equip the tourist with the means to express him-/herself in a language characterised by formal grammatical correctness.

However, some dictionaries go far beyond the needs of the average tourist in this respect. US 2004, for example, provides the tourist with a very thorough and intricate overview of the system of verb inflections in Spanish. The overview first divides the Spanish verbs into three inflectional groups and then gives the inflectional forms for infinitive, present and past participle, present indicative, present continuous, past simple, future, present perfect, past perfect and imperfect past. For all the finite categories we get the forms for the whole person range. This is followed by the whole range of forms for the auxiliary verbs ser, estar and tener (but not haber), and finally six frequent irregular verbs, although here the information given is for some reason restricted only to infinitive, present indicative, past simple, imperfect past and future, and for the finite categories only to 1st person singular. Other dictionaries are more restricted and focused in this respect, although the inflectional information given is still beyond what the average tourist needs.

Much in line with conventional bilingual lexicography in French (cf. Hovmark 2005), the FDDFMO travel dictionary brings information on the regular inflectional patterns of French verbs in an outside matter:

1. the -er group inflectional pattern

2. the -ir group inflectional pattern

3. the -re group inflectional pattern

4. the inflectional pattern of the auxiliary verb être (be)

5. the inflectional pattern of the auxiliary verb avoir (have)

as well as an alphabetical list of the following more or less irregular verbs (6 to 108): 


6. absoudre (absolve)
7. accueillir (welcome)
8. acheter (buy)
9. acquérir (acquire)
10. aller (go)
11. apercevoir (catch sight of)
12. appeler (call)
13. apprécier (appreciate)
14. assaillir (assault)
15. s'asseoir (sit)
16. assiéger (besiege)
17. battre (hit)
18. boire (drink)
19. bouillir (boil)
20. broyer (grind)
21. céder (give up)
22. clore (close)
23. concevoir (conceive)
24. conclure (conclude)
25. confire (candy)
26. connaître (know)
27. contraindre (force)
28. convaincre (convince)
29. coudre (sew)
30. courir (run)
31. couvrir (cover)
32. craindre (fear)
33. créer (create)
34. croire (believe)
35. croître (grow)
36. cueillir (pick)
37. cuire (cook)
38. décevoir (disappoint)
39. défaillir (faint)
40. devoir (must)

41. dire (say)
42. dissoudre (dissolve)
43. dormir (sleep)
44. écrire (write)
45. envoyer (send)
46. essuyer (dry)
47. exclure (exclude)
48. faillir (fail)
49. faire (do, make)
50. falloir (have to)
51. foutre (do)
52. fuir (escape)
53. haïr (hate)
54. inclure (include)
55. interdire (forbid)
56. jeter (throw)
57. joindre (join)
58. lire (read)
59. luire (shine)
60. manger (eat)
61. maudire (curse)
62. se méfier (mistrust)
63. mentir (lie)
64. mettre (put)
65. modeller (model)
66. moudre (grind)
67. mourir (die)
68. mouvoir (move)
69. naître (be born)
70. nuire (harm)
71. offrir (offer)
72. ouvrir (open)
73. paraître (seem)
74. partir (leave)
75. payer (pay)

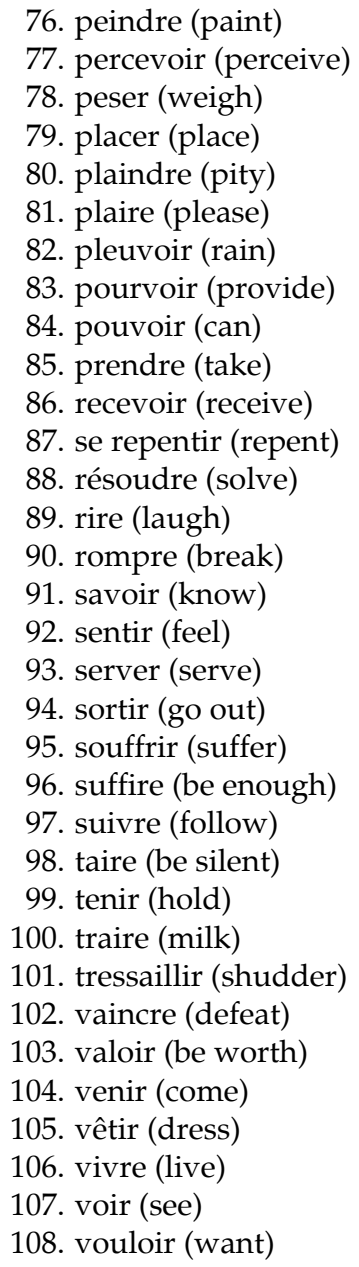

The list contains information on the irregular forms used in the following tenses: present, perfect, imperfect, future, conditional and subjunctive. The full conjugation pattern is only given for the present tense, whereas nothing is explained about the function of the other forms and tenses (expressing differences of time, aspect and modality). The real problem however is not the fact that (complete) grammatical information is lacking but that the grammatical data type 'irregular verbs and their inflections' is functionally speaking inconsequential and irrelevant to the tourist user. The verbs are for many different reasons useless in conventional tourist user situations, either because their usage is archaic (22: clore), extremely vulgar (51: foutre), very rare (35: croittre, 68: mouvoir, 87: se repentir, 101: tressaillir), highly specialised (6: absoudre in the field 
of religion, 16: assiéger in the field of military tactics, and 100: traire in the field of cattle breeding), or simply because they are only inflected in one single form (66: moudre $\rightarrow$ moulu, when speaking about coffee). As already pointed out in the case of the Spanish verb examples, the information given there goes far beyond the functional needs of the average tourist with regard to formal grammatical correctness and can merely be interpreted as a case of lexicographic conservatism resulting in lexicographic cloning.

To sum up, it appears, functionally speaking, that the representation of inflectional data far exceeds the average tourist needs in punctual (functions (c) and (d)) as well as in systematic consultation situations ((a), (e) and (f)). The inflectional data also take up considerable space, consequently severely reducing the amount of grammatical data needed.

\subsection{Helping to construct sentences}

In general, the mini-grammars of the dictionaries do not give much information about syntactic matters. There are however occasional remarks on matters such as 'word order', for example:

\section{I'm travelling to Berlin \\ Ich fahre nach Berlin \\ (lit: I travel to Berlin)}

\section{Tomorrow I'm travelling to Berlin}

Morgen fahre ich nach Berlin

(lit: tomorrow travel I to Berlin)

In a straightforward German statement, the verb is the second element (note that this does not necessarily mean it's the second word as the first element can contain more than one word). The verb would usually follow the subject, i.e., the concept or thing you're talking about. So if you start the sentence with a word like 'tomorrow', you have to reverse the order of the subject and verb to keep the verb in second spot, as illustrated above. (LPG 2003: 24)

Or:

I'm looking for a comfortable hotel

Je cherche un hôtel confortable (lit: I look-for a hotel comfortable)

As a rule, adjectives come after the noun in French. There are exceptions, however, two useful ones to know being 'big' (grand) and 'small' (petit) which come before the noun. (LPF 2003: 16)

Otherwise, in this respect, the tourist is left to deductive reasoning from the phrases. However, in most cases it is not essential for successful communication that every sentence contains the correct number of clause constituents, 
whereas correct constituent order is in many cases essential in, for example, distinguishing between the statement of a declarative sentence and the question of an interrogative sentence. This aspect will be further discussed under 5.7 below.

\subsection{Helping to pick up the right word or the right phrase}

The dictionaries provide explicit semantic information for productive purposes in the form of general $\mathrm{L}_{1} \rightarrow \mathrm{L}_{2}$ dictionaries and a number of thematic $\mathrm{L}_{1} \rightarrow \mathrm{L}_{2}$ dictionaries, such as for example a list of useful words if you stay at a youth hostel (PER 2005: 69) or the words you need to describe problems with your car (US 2004: 57-58).

They also provide explicit semantic information for receptive purposes in the form of general $\mathrm{L}_{2} \rightarrow \mathrm{L}_{1}$ dictionaries and again a number of thematic $\mathrm{L}_{2} \rightarrow \mathrm{L}_{1}$ dictionaries such as a list of terms you may find on menus in restaurants (GSEP 2005: 112-118), or words you may hear from the mechanic in case your car breaks down (US 2004: 59-60), under the assumption, that is, that you have studied the transcriptions of the words and phrases so as to be capable of recognizing for example the following:

[leempyah-pahrahbreesahs]

which is 'Spanish' for windshield wiper.

The approximate number of entries in the general dictionaries and in the thematic dictionaries for tourists with France as their destination appears from the table below:

\begin{tabular}{|l|c|c|}
\hline & English/Danish $\rightarrow$ French & French $\rightarrow$ English/Danish \\
\hline Lonely Planet & 2600 & 2500 \\
\hline Rough Guide & 4400 & 3400 \\
\hline Gyldendal & 2900 & 2800 \\
\hline Politiken & 1700 & 1000 \\
\hline
\end{tabular}

It should be observed, however, that whereas the entries in the thematic dictionaries are on the whole included in the general dictionaries Lonely Planet, Rough Guide and Gyldendal, this is not the case with Politiken. The total number of entries in Politiken is therefore probably the same as in Lonely Planet and Gyldendal.

In general, the selection of entries seems to be appropriate, for the words and phrases selected will - to a large extent - cover the semantic-communicative needs of the average tourist, thus more or less fulfilling functions (c) and (d). One may wonder, however, how words such as activist, antinuclear and deforestation have found their way into the general $\mathrm{L}_{1} \rightarrow \mathrm{L}_{2}$ Lonely Planet dictionary. It can hardly be imagined how a tourist with a very limited knowledge of 
French would engage in communicative situations that would require the use of such words.

\subsection{Helping not to sound rude}

Stylistic information helps tourists select words and phrases that fit in with the given communicative situation in terms of levels of politeness and formality. Such information is actually scarce in the dictionaries investigated, but there are occasional remarks such as the following from the section on pronouns in the chapter 'How the language works' in RGF (2006: 245):

YOU: tu is used when speaking to someone who is a friend, or to someone of your own general age group with whom you want to establish a friendly atmosphere. Vous is used when speaking to several friends (i.e. it is the plural of tu) or when speaking to someone you don't know. In the vast majority of cases, as a foreigner in France you will use the vous form. Certainly, if you are in any doubt as to which form to use, choose the vous form.

The following from the chapter 'How the language works' in RGG 2006, the section on modal verbs in the mini-grammar in PER 2005, and the section 'Language Difficulties' in LPG 2003 fall into the same category:

In the English-German section, when two forms of the verb are given in phrases such as 'can you ...? kannst du / können Sie ...?' the first is the familiar and the second the polite form ... (RGG 2006: 241)

Man bruger ofte datidsformerne når man henvender sig til nogen på en høflig måde:

The past tense forms are often used when approaching somebody in a polite way:

Could you tell me when the bus leaves?

Kan De sige mig hvornår bussen går?

Would you like a cup of tea?

Vil du have en kop te? (PER 2005: 180)

There are two forms of the second person singular pronoun 'you'. Use the polite form Sie with anyone you don't know well. You should only use the informal form $d u$ with people you know very well. All the phrases in this chapter use Sie - use your intuition to work out when to use formal and informal forms. (LPG 2003: 25)

Occasionally, the dictionaries will provide information about the level of formality of the entry. The entry 'appointment' in the general $\mathrm{L}_{2} \rightarrow \mathrm{L}_{1}$ dictionary of GSEP 2005 is thus given the label 'formal'.

It is somewhat surprising that dictionaries, which devote whole chapters 
to an explicit treatment of grammatical correctness, do very little (explicitly) to equip the tourist with the linguistic means with which to select words and phrases that fit the given communicative situation in terms of politeness and formality. One explanation for this could be that the writers of the dictionaries feel that they have dealt sufficiently implicitly with this aspect in their selection of phrases in the situational-contextual chapters. It can therefore be concluded that the grammatical data assigned to information on formality and politeness fail to fulfil their intended functions at the stylistic level: helping tourists not to sound rude (functions (c) and (d)).

\subsection{Helping to do things with words}

Information about pragmatics comes in various forms in the dictionaries. The main justification for the dictionary is in fact to equip the tourist with a number of speech acts which, if used appropriately and phrased correctly, will accomplish his/her communicative goals in any given speech situation. The following examples of speech acts all come from LPF 2003.

One typical speech act is 'requesting information':

What level is that slope?

Quelle est la difficulté de cette piste?

Another is 'requesting a (physical) thing':

Same again please.

La même chose, s'il vous plaît.

It could be an 'offer':

I'll buy you a drink.

Je vous offre un verre.

Or a 'compliment':

You're a fantastic dancer.

Tu danses vraiment bien.

However, we have some difficulty in classifying the following phrase found under the section 'Romance' in LPG (2003: 113). It is particularly unclear what other professions could be inserted into the parentheses with the same perlocutionary effect, whatever it is:

Before this goes any further, I must be upfront. I'm an (accountant).

Bevor wir uns näher kennen lernen, muss ich etwas klarstellen. Ich bin (Buchhalter/Buchhalterin).

All of these of course give implicit information about the performance of speech acts in the foreign language, but very often the dictionaries will also provide explicit information about speech acts and how to perform them. 
The following from PFR (2005: 204) illustrates explicit instruction in how to phrase a specific speech act:

\section{SPØRGSMÅL QUESTIONS}

Et spørgsmål som fx Har De et værelse? kan formuleres på tre måder: A question such as Har De et værelse? can be formulated in three ways:

1. Avez-vous une chambre? dvs. ved omvendt ordstilling ligesom på dansk. i.e. by inversion like in Danish.

2. Vous avez une chambre? dvs. ved blot at hæve tonen sidst i sætningen (ligesom man kan gøre i nogle spørgsmål på dansk).

i.e. by raising intonation at the end of the sentence (in the same way as it is possible in some questions in Danish).

3. Est-ce que vous avez une chambre? dvs. ved at sætte spørgefrasen est-ce que, som udtales [æske], foran.

i.e. by putting the question phrase est-ce que, which is pronounced [æske] in front.

Similar explicit instruction is found in LPG (2003: 23-24):

\section{yes / no questions}

The hotel is on Potsdamer Square?

Das Hotel ist am Potsdamerplatz?

(lit: the hotel is on-the Potsdamer-square)

There are three main ways of forming yes/no questions. The one which requires least effort is to make a statement, but to say it like a question, rising in intonation towards the end of the sentence, as illustrated above.

The hotel is on Potsdamer Square, isn't it?

Das Hotel ist am Potzdamerplatz, nicht wahr?

(lit: the hotel is on-the Potsdamer-square not true)

The second example shows that you can also add nicht wahr (not true) to the end of a statement. This is much easier than in English, where you'd use a variety of question tags, such as 'isn't it?', 'aren't you?' and 'doesn't it?'

Is the hotel on Potsdamer Square?

Ist das Hotel am Potsdamerplatz?

(lit: is the hotel on-the Potsdamer-square)

Finally, the third example shows you can turn a statement into a question by reversing the order of the subject and the verb.

The literal illustration of word order in the syntactic construction of L2 sentences is sometimes deliberately elucidated in the articles of the phrase book, as in LMP 2004. The examples below are taken from a conversational section containing sentences that might be useful in a bargaining situation (from the 
very first line 'how much is this sculpture' to the last line 'here is your money, don't you have any change?'):

\author{
Lafo kosa izany ka! \\ lafou koussa zani ka \\ cher quand-même cela hein (= expensive however this eh) \\ Que c'est cher!
}

Tsy lafo iazany sady tsara tarehy koa anie io e!

tssi lafou zani ssadi tssara taré kou ani-é i-ou é

ne-pas cher cela est beau aspect aussi voyez-vous ceci ( = not expensive this is beautiful aspect also see-you this)

Ce n'est pas cher et elle est belle n'est-ce pas?

As already argued above, the data included in the 'example of a complete bargaining conversational exchange' are so idiosyncratic that they do not fulfil any productive or receptive function whatsoever (functions (c) and (d)). The lack of functional usability also applies to the data type 'L1 translation of literary L2 word order' in association with the 'natural L2-L1 translation' data type. This type of data selection and presentation merely reproduces the conventions of a linguistic style sheet tradition in journals of linguistics, in which it is necessary that the reader gains direct access to knowledge on the syntactic constraints of the so-called exotic languages in terms of word order and grammatical categories. As the French-Malagasy is intended for the tourist (cf. the foreword p. 1) and not for the linguist, and as the grammatical rules given for word order in the mini-grammar of the book (pp. 13-14) are clearly insufficient, the only lexicographic function we can think of is a knowledge-oriented function, namely contrastive knowledge of word order in Malagasy, which clearly fails to fall in under cognitive functions (e) and (f). Furthermore, the words used in the sentence examples of the situational part are not even lemmatised in the bilingual word list, the phrase book consequently failing here to assist with any possible reception problems.

An important aspect of pragmatic competence is knowledge of how to engage in 'phatic communion' and knowledge of the essential politeness phrases. These aspects are covered extensively in all the dictionaries investigated. GSE 2005 for example has a whole chapter (17 pages in length) with examples of how to greet people, politeness phrases, phrases expressing opinions and emotions, compliments, small talk, etc.

An essential problem with all this is, however, to what extent this plethora of phrases is essential to the basic communicative needs of the tourist. It is not essential for the tourist who walks into a, say, French pharmacy to buy painkillers to be conversant with a whole range of different ways of expressing the speech act 'requesting a thing'. The conventions of the social and communicative situation in which he/she finds him-/herself will in fact define almost all aspects of the situation, so that all he/she needs to do is to utter the French word for painkillers. The conventions of the situation will see to the rest. 


\subsection{Helping to speak and behave correctly}

The following data from the 'savoir vivre' section of LMP 2004 illustrate explicit instructions in how to phrase a specific speech act and how to use the appropriate body language in the context of greetings and politeness - here to show respect to the elderly:

S'il vous arrive de passer devant une personne âgée, vous devrez dire azafady tompoko, s'il vous plaît monsieur/madame, tout en vous courbant un peu.

If you happen to pass before an elderly person, you must say azafady tompoko, please sir / madam, while slightly bowing.

The problem, however, is that these important cultural instructions and phrases are not integrated in any way in the distribution structure of the dictionary (situational sections and/or bidirectional wordlists) and are thus not easily accessible to the user (see Gouws 2007 for functional propositions with regard to the microstructural integration of cultural data types).

\section{Conclusions - mixing the characteristics of bilingual and learners' dictionaries}

Our investigation of travel dictionaries has revealed the functional dilemma of grammatical data which jeopardises the efficiency of lexicographic tools designed for tourists at a beginner level. As symptomatically stated by the RGF 2006 in its foreword - 'The RGF dictionary is a highly practical introduction to contemporary language' - travel dictionaries seem to be perfectly aware of their double identity, simultaneously bilingual dictionaries and learners' dictionaries. They intend to be used as practical tools, and yet do not admit frankly that their usability is subject to their potential users' participation in active language learning processes. In other words, one might say that travel dictionaries somehow do not attempt to free themselves from their pedagogical constraints.

The functional dilemma then lies in the fact that communicatively oriented grammatical assistance is determined by punctual consultation scenarios, whereas cognitively oriented grammatical assistance is determined by systematic consultation scenarios triggered by the shortcomings of the communicative assistance; accordingly it lies in the fact that the two consultation scenarios, while being interdependent, are temporally determined.

Our study has also revealed the overall predominance of the linguistic approach, with a disproportionate focus on correctness. It means that no clear choice is made with regard to the nature of the lexicographic assistance provided by the grammatical data: the two sets of orientations remain separated instead of being integrated in the overall data distribution structure. Travel dictionaries are caught between the bilingual and the pedagogical legacy of 
lexicography for users of a foreign language, between cognition and communication; they want to do both, but fail to deal with the asynchronicity of their intertwined orientations.

The resolution of the dilemma of grammatical data lies in mixing the lexicographic characteristics and conceiving bilingualised learners' dictionaries which are less ambitious with regard to linguistic correctness, but far more ambitious with regard to the integration of pedagogical grammatical data for language learning and practising. In order to ensure flexible and easy access to the grammatical data, this development could best be achieved by the publication of online travel dictionaries linked to associated online basic language courses, whereby consultation asynchronicity would truly become a functional asset.

\section{Note}

$\dagger \quad$ In this article, we will simply use the term 'travel dictionary' and abandon the term 'phrase book', much in line with Bergenholtz and Bergenholtz (2007) who argue: 'The titles of lexicographic tools - dictionary, lexicon or encyclopaedia - are normally just names given to them by the publishers, although you may point out certain differences between certain types.' In our case, there are no differences, as both terms refer to types of lexicographic tools designed for tourists in order to provide the same kind of lexicographic assistance with the same kind of lexicographic resources.

\section{Literature}

\section{Dictionaries}

Assimil Évasion. 2004. Le Malgache de poche. (LMP)

Gyldendals Store Engelsk Parlør. 2005. Copenhagen: Gyldendalske Boghandel, Nordisk Forlag A/S. (GSEP)

Gyldendals Store Fransk Parlør. 2005. Copenhagen: Gyldendalske Boghandel, Nordisk Forlag A/S. (GSFP)

Lonely Planet French. 2003. Second edition. Victoria: Lonely Planet Publications. (LPF)

Lonely Planet German. 2003. Second edition. Victoria: Lonely Planet Publications. (LPG)

Lonely Planet Ethiopian Amharic Phrase Book. 2002. Victoria: Lonely Planet Publications (LPEA)

Politikens Engelsk Rejseparlør. 2005. Copenhagen: Politikens Forlag. (PER)

Politikens Fransk Rejseparlør. 2005. Copenhagen: Politikens Forlag. (PFR)

Politikens Miniordbog Fransk. 2002. Fransk-Dansk/Dansk-Fransk Miniordbog. Copenhagen: Politikens Forlag. (FDDFMO)

Rough Guide French. 2006. Second edition. London: Rough Guides Ltd. (RGF)

Rough Guide German. 2006. Second edition. London: Rough Guide Ltd. (RGG)

Ulysses Spanish for Better Travel in Spain. 2004. Ulysses Travel Guides. (US) 


\section{Theoretical contributions}

Abend, Heike. 1991. Das Reisewörterbuch. Hausmann, Franz Josef, Oskar Reichmann, Herbert Ernst Wiegand and Ladislav Zgusta (Eds.). 1989-1991: 2903-2908.

Andersen, Birger. 2007. Dictionary Grammars. Hermes, Journal of Language and Communication Studies 38: 119-136.

Bergenholtz, Henning and Inger Bergenholtz. 2007. Kvaliteten af de leksikografiske definitioner i ordbøger, leksika og encyklopædier. LexicoNordica 14: 11-33.

Gouws, Rufus. 2007. The Selection, Presentation and Treatment of Cultural Phrases in a Multicultural Dictionary. Lexicographica 22: 24-36.

Hausmann, Franz Josef, Oskar Reichmann, Herbert Ernst Wiegand and Ladislav Zgusta (Eds.). 1989-1991. Wörterbücher. Ein internationales Handbuch zur Lexikographie/Dictionaries. An International Encyclopedia of Lexicography/Dictionnaires. Encyclopédie internationale de lexicographie. Third volume. Handbücher zur Sprach- und Kommunikationswissenschaft 5.3. Berlin/New York: Walter de Gruyter.

Hovmark, Henrik. 2005. Tre franske miniordbøger til rejsebrug og daglig tale. LexicoNordica 12: 213-231.

Leroyer, Patrick. 2007. Maultasche og Novillada: En teori for turistordbøger. Nordiske studier for leksikografi 9. Konference om leksikografi i Norden, Akureyri, Island, 23-24 maj 2007. [In print.]

Leroyer, Patrick. 2008. Du support d'information á l'outil lexicographique: la lexicographisation du guide touristique. Bernal, Elisenda and Janet DeCesaris (Eds.). 2008. Proceedings of the XIII EURALEX International Congress, Barcelona, 15-19 July 2008: 879-886. Sèrie Activitats 20. Barcelona: Universitat Pompeu Fabra, Institut Universitari de Lingüística Aplicada.

Mogensen, Jens Erik. 2005. Grammatik im Wörterbuch. Barz, Irmhild, Henning Bergenholtz and Jarmo Korhonen (Eds.). 2005. Schreiben, Verstehen, Übersetzen, Lernen. Zu ein- und zweisprachigen Wörterbüchern mit Deutsch: 189-202. Finnische Beiträge zur Germanistik 14. Frankfurt a.M.: Peter Lang.

Mugdan, Joachim. 1989. Grundzüge der Konzeption einer Wörterbuchgrammatik. Hausmann, Franz Josef, Oskar Reichmann, Herbert Ernst Wiegand and Ladislav Zgusta (Eds.). 19891991: 732-749.

Tarp, Sven. 2008. Lexicography in the Borderland between Knowledge and Non-Knowledge. General Lexicographical Theory with Particular Focus on Learner's Lexicography. Lexicographica. Series Maior 134. Tübingen: Max Niemeyer.

Wen-Chao Li, Chris. 2007. Foreign Names into Native Tongues. How to Transfer Sound between Languages - Transliteration, Phonological Translation, Nativization, and Implications for Translation Theory. Target 19(1): 45-68. 